NASA Technical Memorandum 4590

Flight Testing a Propulsion-Controlled Aircraft Emergency Flight Control System on an F-15 Airplane

F.W. Burcham, Jr., John Burken, and Trindel A. Maine Dryden Flight Research Center

Edwards, California

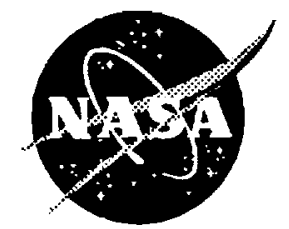

National Aeronautics and

Space Administration

Office of Management

Scientific and Technical Information Program 
= 


\title{
FLIGHT TESTING A PROPULSION-CONTROLLED AIRCRAFT EMERGENCY FLIGHT CONTROL SYSTEM ON AN F-15 AIRPLANE
}

\author{
F.W. Burcham, Jr: \\ John Burken"* \\ Trindel A. Maine ${ }^{\dagger}$ \\ NASA Dryden Flight Research Center \\ Edwards, Califormia
}

\begin{abstract}
Flight tests of a propulsion-controlled aircraft (PCA) system on an F-15 airplane have been conducted at the NASA Dryden Flight Research Center. The airplane was flown with all flight control surfaces locked both in the manual throttles-only mode and in an augmented system mode. In the latter mode, pilot thumbwheel commands and aircraft feedback parameters were used to position the throttles. Flight evaluation results showed that the PCA system can be used to land an airplane that has suffered a major flight control system failure safely. The PCA system was used to recover the F-15 airplane from a severe upset condition, descend, and land. Pilots from NASA, U.S. Air Force, U.S. Navy, and McDonnell Douglas Aerospace evaluated the PCA system and were favorably impressed with its capability. Manual throttles-only approaches were unsuccessful. This paper describes the PCA system operation and testing. It also presents flight test results and pilot comments.
\end{abstract}

\section{Nomenclature}

$\begin{array}{ll}\text { AGL } & \text { above ground level } \\ \text { CAS } & \text { control augmentation system } \\ \text { DEEC } & \text { digital electronic engine control } \\ \text { HIDEC } & \text { Highly Integrated Digital Electronic Control } \\ \text { HUD } & \text { heads-up display } \\ \text { KIAS } & \text { knots indicated airspeed }\end{array}$

\footnotetext{
*Chief, Propulsion and Performance Branch, AIAA Associate Fellow

"Aerospace Engineer

${ }^{\dagger}$ Senior Aerospace Analyst

Copyright $\odot 1994$ by the American Institute of Aeronautics and Astronautics, Inc. No copyright is asserted in the United States under Title 17, U.S. Code. The U.S. Government has a royalty-free license to exercise all rights under the copyright claimed herein for Govemmental purposes. All other rights are reserved by the copyright owner.
}

MDA

MSL McDonnell Douglas Aerospace, St. Louis, Missouri

$\mathrm{NCI}$ navigation control indicator

PCA propulsion-controlled aircraft

V airspeed, $k$ ts

$\alpha \quad$ angle of attack, deg

\section{Introduction}

After a major flight control system failure, the crew of a multiengine aircraft may use throttle manipulation for emergency flightpath control. Differential throttle control generates sideslip, which through dihedral effect, results in roll. Symmetric throttle inputs may be used to control pitch. Pilots of at least four wide-body aircraft have had to use throttles for emergency flight control. ${ }^{1}$ These aircraft include the DC-10 (McDonnell Douglas Aerospace (MDA), Long Beach, California), B-747 (Boeing Company, Scatte, Washington), and L-1011 and C-5 (Lockheed Corporation, Burbank, California).

To investigate the use of engine thrust for emergency flight control, the National Aeronautics and Space Administration, Dryden Flight Research Center (NASA Dryden), Edwards, California, has been conducting flight, ground simulator, and analytical studies. One objective is to determine the degree of control power available for various classes of airplanes. This objective has shown a surprising amount of control capability for most multiengine airplanes. A second objective is to provide awareness of throttles-only control capability and suggested manual throttles-only control techniques for pilots. Results of simulation and flight studies of several airplanes, including the B-720, B-727, B-747, Lear 24 (Gates Learjet, Wichita, Kansas), and F-15 (McDonnell Douglas Acrospace, St. Louis, Missouri), and recommended procedures for manual throttles-only flight have been reported. ${ }^{2}$ Another 
objective is to investigate control modes that could be developed for future fighter and transport airplanes. An augmented control system that uses pilot flightpath and bank angle inputs and sensor feedbacks to provide throttle commands for emergency landings was developed and evaluated on a transport airplane simulation ${ }^{3}$ and on an F-15 simulation. ${ }^{4}$

In 1993, a flight test program on the NASA F-15 airplane investigated the performance of the PCA system, and landings using PCA control were completed. ${ }^{5,6}$ The PCA recoveries from upset conditions, including $90^{\circ}$ banks at $20^{\circ}$ dives, were flown. In addition, the PCA envelope was expanded well beyond its original design in speed and bank angle. During the flight test program, eight pilots flew the F-15 airplane with the PCA system. Manual throttes-only approaches were also attempted and compared with PCA approaches.

This paper summarizes the flight tests of the PCA-augmented system for the F-15 airplane. Test techniques, results of PCA landings, PCA recoveries from upsets, manual throules-only approaches, and pilot comments are presented. Principles of throtules-only control were previously reported and will not be further discussed in this paper. ${ }^{5}$

\section{Description of F-15 Airplane and Instrumentation}

Figure 1(a) shows the F-15 airplane under PCA control, and figure 1(b) shows a three-view drawing of this airplane. This high-performance fighter airplane has a maximum capability of Mach 2.5 and a high wing with $45^{\circ}$ of leading-edge sweep and twin vertical tails. The airplane is powered by two F100 afterbuming turbofan engines (Pratt \& Whitney (P\&W), West Palm Beach, Florida) mounted close to the centerline ( $4.25 \mathrm{ft}$ apart) in the aft fuselage. As is typical of fighter airplanes, the propulsion system is highly integrated into the fuselage. This airplane has been used in the Highly Integrated Digital Electronic Control (HIDEC) program for numerous integrated flight propulsion controls system research experiments in the last $10 \mathrm{yr}$.

The developmental F100 engine model derivative (EMD) engines are installed in the NASA F-15 airplane. These engines (PW1128) include a redesigned fan, which was later incorporated into the F100-PW-229 engine, and other improvements. The F100 EMD engines are controlled by a digital electronic engine control (DEEC). Prototype control system software was incorporated into these EMD engines. As an unfortunate side effect, this software produced slower than production engine response characteristics at low-power settings. For the PCA tests, afterburning was not used; throule setuings were limited to intermediate and below.
External compression horizontal ramp inlets with variable geometry are mounted on the sides of the forward fuselage. A variable-capture-area capability exists in which the inlet cowl rotates about a point near the lower cowl lip. At subsonic speeds, the inlet cowl angle is normally positioned by a control system as a function of angle of attack. If the inlet control system fails, if hydraulic pressure is lost, or if the pilot selects it, the inlets go to the full up "emergency" position.

The NASA F-15 flight control system features the standard mechanical flight control system and a digital control augmentation system (CAS). For throttles-only control research, the CAS can be turned off. In addition, the mechanical pitch and roll ratio changer system can be operated in an emergency mode which eliminates any flight control system response except that caused by pilot inputs. For all data shown in this paper, "CAS-off" refers to this CAS-off pitch and roll ratios emergency configuration.

\section{Augmented Control Mode}

Figure 2(a) shows the features of the PCA system on the F-15 airplane. Figure 2(b) shows the location of the PCA installation in the F-15 cockpit. Except for a thumbwheel controller panel, the PCA system used equipment which had been previously installed. This panel consists of ana$\log$ devices with continuous output used by the pilot to command flightpath and bank angle. The various avionics and PCA units communicate with each other through digital data buses. The logic for the PCA control laws resides in the general-purpose research computer and is written in FORTRAN. Digital inputs are received from the digital flight control system, inertial navigation set, airdata computer, digital engine controls, and pilot's flightpath and bank angle thumbwheels. The PCA system sends throttle commands to the internal DEEC electronic throtle command logic without driving the throttle levers in the cockpit. These commands are limited to the idle-tointermediate-power range. No commands are sent to the inlets during PCA operation. The pilot may also send inputs to the PCA logic through the navigation control indicator (NCI) keyboard on the right console.

Figure 3 shows the PCA control laws. These laws were developed using classical means using root locus and Bode analysis. In the pitch axis, pilot thumbwheel command for flightpath angle is compared to the sensed fightpath angle, with flightpath angle rate as the primary feedbacks. Velocity feedback was also used in some cases to assist in phugoid damping. Symmetric (equal) thrust commands are sent to both engines to obtain the commanded flightpath. The thumbwheel flightpath command is displayed to the pilot on the heads-up display (HUD) using a small box symbol (fig. 2(b)). This display provides 
flight information, such as airspeed and altitude. A velocity vector symbol is available for determining the precise flightpath relative to the ground. Flightpath command limits are $15^{\circ}$ to $-10^{\circ}$.

In the roll axis, the pilot bank angle command is compared to stability axis yaw rate and to bank angle. Differential thrust commands are issued to both engines to obtain the commanded bank angle. Bank angle command limits are $\pm 30^{\circ}$. Numerous automatic features were installed to disengage the PCA system in case of malfunction, exceedance of predefined limits, or pilot movement of the stick or throttles.

The pitch and roll axis control laws were developed by MDA and NASA Dryden using linear models, nonlinear batch simulations, and nonlinear piloted simulations. Extensive flexibility was built into the PCA software. This flexibility permits the pilots to change almost all gain schedules, table values, filters, logic options, and control modes in flight. Such flexibility proved invaluable during the flight tests.

The F-15 airplane was instrumented to measure the parameters required for the throtules-only flights. Such flight test engine and airplane parameters as airdata, attitudes, rates, positions, and temperatures were measured. A radar altimeter was added. The HUD video and a continuously recording pilot microphone were invaluable for evaluating the PCA system and pilot comments. All of this information was recorded onboard and telemetered to the ground for recording and real-time display in the control room.

\section{F-15 Simulations}

Two F-15 simulations were used in this study: one at NASA Dryden and the other at MDA. The NASA Dryden F-15 simulation was a fixed-base, full-envelope, sixdegree-of-freedom aircraft simulation. This model contained nonlinear aerodynamics and a nonlinear flight control system as well as an engine model which was developed to represent the F100 EMD engines. The initial control laws and a model of inlet effects because of airflow variation were developed and incorporated. ${ }^{4}$ The PCA flight control logic was incorporated for control law evaluation and development. The NASA Dryden simulator was also used for pilot training, particularly for the guest pilots.

The fixed-base simulation at MDA featured an F-15 cockpit and a very-high-fidelity visual capability, incorporating scenery projected onto a $40-\mathrm{ft}$ dome. The acrodynamic, control system, and propulsion system models were similar to those at NASA Dryden. For the PCA simulation tests, the PCA control logic was incorporated for control law evaluation and development. For the verification and validation tests, the flight software was installed in flight control computers. An F-15 HUD, NCI panel, and flight thumbwheels were used for the piloted hardware-in-the-loop tests.

\section{Test Techniques}

Test techniques were developed to assess the throttles-only control capability of the F-15 airplane and simulation. To avoid the presence of flight control system inputs, the CAS was turned off, and the emergency mode was selected for the mechanical system. In this mode, the flight control surfaces would not move as long as the pilot did not move the stick or rudder pedals. The inlet was moved to its emergency position which would occur if hydraulic pressure were lost. For low-speed approach and landing tests, the landing gear and electrically powered flaps were lowered. The pilot trimmed the airplane to the desired airspeed and then released the flight controls.

In-flight, open-loop, throttles-only tests, including small and large-throttle steps, were flown. Control performance was observed and compared to the simulation. Later, the augmented PCA system tests were conducted making small step commands in pitch and roll in level flight at several flight conditions.

Combinations of pitch and roll commands were tested, followed by PCA approaches to gradually lower altitudes until PCA landings were made. Manual throttles-only control techniques, including approaches, were also used for comparison: All approaches were made to the Edwards main runway 22 . This runway is $15,000 \mathrm{ft}$ long and $300 \mathrm{ft}$ wide, with an elevation of $2,274 \mathrm{ft}$ above mean sea level (MSL).

Another test was devised to determine the ability of the PCA system to recover the F-15 airplane from other than trimmed level flight. Simulator tests showed that PCA could be engaged at an upset condition, such as a $90^{\circ}$ bank and a $20^{\circ}$ dive, starting from a speed of $260 \mathrm{kts}$. The procedure was as follows:

1. Trim straight and level at $260 \mathrm{kts}$ and from 10,000 to $12,000 \mathrm{ft}$ with CAS-off.

2. Fly the airplane to about $10^{\circ}$ nose up.

3. Roll to $90^{\circ}$ bank.

4. Release the controls.

5. Select "inlets emergency" to simulate the loss of hydraulics to the inlet ramps.

6. Engage PCA as the nose drops through $-10^{\circ}$.

The PCA pitch control laws included velocity feedback for these high-speed cases. 
Eight pilots flew the PCA system (table 1). All were test pilots with varying degrees of experience. A series of flight cards was developed to demonstrate the PCA system capabilities and allow the pilots to evaluate its performance.

Table 1. Pilots for the propulsion-controlled aircraft flight evaluation.

\begin{tabular}{|c|c|c|}
\hline Pilot & Affiliation & Current Assignment \\
\hline $\bar{A}$ & $\overline{\text { NASA }}$ & $\begin{array}{l}\text { Dryden F-15 PCA Project Pilot, } \\
\text { Edwards, California }\end{array}$ \\
\hline B & NASA & $\begin{array}{l}\text { Dryden F-15 Project Pilot, } \\
\text { Edwards, California }\end{array}$ \\
\hline C & USAF & $\begin{array}{l}\text { Guest, Experimental Test Pilot, } \\
\text { 445th Test Squadron, Edwards } \\
\text { AFB, Califomia }\end{array}$ \\
\hline $\mathrm{D}$ & MDA & $\begin{array}{l}\text { Guest, Contractor Test Pilot, F-15 } \\
\text { Combined Test Force, } \\
\text { Edwards AFB, California }\end{array}$ \\
\hline E & NASA & $\begin{array}{l}\text { Guest, Dryden F-18 Project Pilot, } \\
\text { Edwards, California }\end{array}$ \\
\hline F & NASA & $\begin{array}{l}\text { Guest, Dryden Chief, Flight } \\
\text { Operations, Edwards, Califor- } \\
\text { nia }\end{array}$ \\
\hline G & USAF & $\begin{array}{l}\text { Guest, USAF Test Pilot School, } \\
\text { Edwards AFB, Califomia }\end{array}$ \\
\hline $\mathrm{H}$ & NAVY & $\begin{array}{l}\text { Guest, F-14 Test Pilot, Naval Air } \\
\text { Warfare Center, Patuxent River, } \\
\text { Maryland }\end{array}$ \\
\hline
\end{tabular}

Each guest pilot received a briefing on the PCA concept, its implementation on the NASA F-15, and its predicted performance. The guest pilots then flew the flight test cards in the NASA Dryden simulator. These pilots were allowed to repeat this simulated flight as many times as they desired. Then, a detailed cockpit briefing was given, and the flight followed within 1 to 7 days.

The guest pilots all flew the same tasks which consisted of

- CAS-off flight control and handling qualities evaluation.

- Up-and-away manual throttles-only control-small pitch, then small heading changes, then combined pitch and heading control.

- PCA-engaged step responses and small pitch and roll inputs combined.
- PCA approach to $200 \mathrm{ft}$ above ground level (AGL), disengage, CAS-off touch-and-go landing.

- PCA approach to $100 \mathrm{ft}$ AGL, PCA go-around.

- PCA approach to $50 \mathrm{ft}$ AGL, disengage, CAS-off wuch-and-go landing.

- PCA approach to $20 \mathrm{ft}$ AGL, disengage, CAS-off touch-and-go landing.

- PCA recovery from $260 \mathrm{kts}$ at an altitude of $10,000 \mathrm{ft}$ simulated hydraulic failure and upset, descent, approach to landing, disengage at $20 \mathrm{ft}$ AGL, CAS-off landing.

- Manual throttles-only approach to $200 \mathrm{ft}$ AGL, CAS-off go-around.

\section{Results and Discussion}

This section presents results of the initial throtules-only step response testing, the PCA step response testing, PCA approach-and-landing tests, PCA recovery from upset conditions, and manual throttles-only approach attempts.

Throttles-only step responses were flown to define the airplane response. Differential throttle inputs produced the desired roll response at all tested conditions. Positive pitch response was evident at $150 \mathrm{kts}$ with the thrust increases causing the desired nose-up response. At $170 \mathrm{kts}$ and higher speeds, an effect resulting from the forward placement of the inlets resulted in an initial response which was opposite to the desired response. ${ }^{4}$ Because of this pitch response, PCA approaches were flown at $150 \mathrm{kts}$.

In addition, PCA step responses were flown. At 150 $k t s$, the pitch response was slow but stable. A $2^{\circ}$ step change in flightpath took $10 \mathrm{sec}$. Roll response was faster. A $20^{\circ}$ bank angle step took about $5 \mathrm{sec}$. For small bank angle inputs, an approximately 3 -sec lag occurred.

\section{Propulsion-Controlled Aircraft Approaches and Landings}

Propulsion-controlled aircraft approaches to landing and a PCA go-around were flown, followed by PCA landings. Figure 4(a) shows a time history of the last $56 \mathrm{sec}$ of the first PCA landing. The conditions for this landing included an 8-kt wind down the runway and almost no turbulence. The pilot reduced the flightpath command from $-1.6^{\circ}$ to $-1^{\circ}$ at an altitude of $200 \mathrm{ft}$ and to $-0.4^{\circ}$ at $80 \mathrm{ft}$. A very shallow final approach resulted from these reductions. Pitch commands were few, and almost full time was spent making bank angle commands to maintain runway alignment. At an altitude of $20 \mathrm{ft}, 6 \mathrm{sec}$ before touchdown, the ground effect began to affect the flightpath, primarily with a nose-down pitching moment. The PCA system increased throttle setting and speed to try to counter the ground 
effect, but with no flight control input, the aircraft pitched down to $-1.8^{\circ}$ flightpath at touchdown. At this point, the pilot made an aft stick input to cushion the impact on the nosegear. Bank angle control and lineup were good throughout the final approach. A small correction to the right was made just before touchdown.

Figure 4(b) shows the HUD video view at touchdown. Bank angle at touchdown was $-1^{\circ}$. Touchdown was approximately $8 \mathrm{ft}$ to the left of the runway centerline. The velocity vector was lower than the command because of the ground effect. The pilot rated the pitch control as very good except for the ground effect. Roll control was rated as adequate for this first landing.

Following this landing, another approach was made. In this case (fig. 5), the control tower requested a $360^{\circ}$ turn for spacing 6 miles from the runway at $90 \mathrm{sec}$. The pilot made this turn under PCA control, selecting an immediate $32^{\circ}$ bank. The nose dropped to $-4^{\circ}$ but was recovering when the pilot commanded a slight climb. At $200 \mathrm{sec}$, the pilot rolled out and then continued the approach. On final approach, a steeper flightpath of $-2.5^{\circ}$, then $-1^{\circ}$ was flown until $20 \mathrm{ft}$ when the command was raised to 0 .

In spite of this different technique, the ground effect was similar and touchdown was again at $8 \mathrm{ft} / \mathrm{sec}$. It appeared that all landing sink rates would be at least in the $8 \mathrm{ft} / \mathrm{sec}$ range. Because the landing gear was only capable of sink rates of $10 \mathrm{ft} / \mathrm{sec}$, there was not a large margin for error or variation. Because of their limited experience with the PCA system and the CAS-off F-15 airplane as well as the high sink rate because of ground effect, no actual PCA landings were made by the guest pilots.

\section{Simulated Loss of Control, Upset, and Propulsion-Controlled Airplane Recovery}

Project and guest pilots flew the simulated hydraulic failure induced upset, followed by a PCA system engagement and recovery. Figure 6 shows a time history of pilot $F$ flying this maneuver. The PCA was engaged at an $85^{\circ}$ bank and $-18^{\circ}$ flightpath. The PCA system commanded full differential thrust, rolled the wings level, then reduced thrust to begin the phugoid damping. The pilot put in a bank command to convert some of the excess pitch energy into a tum to reduce the pitchup. Airspeed decayed to $150 \mathrm{kts}$ over the top. After one full pitch cycle, pilot $\mathrm{F}$ lowered the flaps, which caused another pitchup and speed reduction, with speed falling to a minimum of $105 \mathrm{kts}$. The landing gear was extended, and the pitch oscillation was damped quickly. Trim speed was $150 \mathrm{kts}$. Pilot $F$ then tumed back toward the Edwards runway 22 and began a descent with a $-6^{\circ}$ flightpath command. At $450 \mathrm{sec}$, the pilot leveled the airplane and made a turn to start a long straight-in approach to runway 22 . The approach was continued with minimal deviation until $10 \mathrm{ft}$ above the runway and on centerline in perfect position to land, 11 min after the upset.

Figure 6(b) shows the ground track and HUD video for this test, including the last video frame with the radar altimeter reading $10 \mathrm{ft}$. The flightpath velocity vector just below the command box is also shown. At that point, pilot $F$ used the stick to decouple PCA and flared slightly for touchdown.

Figure 7 shows another upset and PCA recovery. In this case, flown by pilot $\mathrm{H}, \mathrm{PCA}$ was engaged at $68^{\circ}$ bank and $-10^{\circ}$ flightpath, a somewhat less severe upset. The PCA commanded a large, but not full, differential thrust. This thrust rolled the wings to nearly level, and the pitch oscillation was damped rapidly. Flaps and landing gear were lowered during a down part of the phugoid, which aided in rapid stabilization of flightpath. In data not shown, pilot $\mathrm{H}$ then turned and began a descent similar to that shown in figure 6. In this latter case, the wind was $280^{\circ}$ at $16 \mathrm{kts}$ with gusts to $26 \mathrm{kts}$, and light to occasionally moderate turbulence. Yet with aggressive bank angle commands, pilot $\mathrm{H}$ was still able to fly under PCA control to $20 \mathrm{ft}$ above the runway and within $10 \mathrm{ft}$ of the centerline.

The F-15 airplane flown with CAS-off has sufficiently poor stability and flying qualities to make it a very challenging application for PCA. The success of the F-15 PCA system in stabilizing a difficult airplane indicates that more stable airplanes, such as large transports, should have better or at least equal success with PCA systems.

\section{Manual Throttles-Only Approaches}

For comparison to the PCA approaches, all pilots flew a manual throttles-only approach. After many attempts at manual approaches, the PCA pilot rated the chances of a safe landing at zero. The guest pilots flew these manual approaches with a minimum of practice, as would be the case in a real emergency.

Figure 8 shows pilot F's manual approach, overlaid over the PCA approach that this pilot had flown 15 min earlier after the upset and recovery. Winds and turbulence were very light. Pilot $F$ had a very difficult time damping the phugoid in the manual mode. Flightpath angle excursions of at least $\pm 3^{\circ}$ and speed variations of as much as $\pm 20 \mathrm{kts}$ from trim speed occurred. The throttles were on the idle stop $\left(18^{\circ}\right)$ much of the time. Bank angle variations were greater than on the PCA approach, and the pilot was never able to get lined up on the runway. The approach was 200 to $1000 \mathrm{ft}$ right of centerline. Heading varied $\pm 3^{\circ}$. Although the average flightpath was the same as for the earlier PCA approach, the extreme variations in flightpath and the difficulty in lineup and heading control would make a safe runway landing extremely unlikely. It might be possible to hit the runway, but not at a safe sink rate. 


\section{Pilot Comments}

In general, pilot comments were very consistent and favorable. A few of the comments of the PCA test pilots and their recommendations for added features are presented here. The project pilot's overall PCA comments are summarized in reference 6 .

Pilot $\mathrm{H}$ evaluated the PCA system flown in the HIDEC F-15 airplane as highly effective as a backup recovery system should an aircraft lose total conventional flight controls. The system was simple and intuitive to use and would require only minimal training for pilots to leam to use it effectively. Of course, landing using PCA would require higher workloads than normal, but this pilot believes such landings could be done safely. The fact that the system provides a simple, straight forward, go-around capability, which allows multiple approaches, furcher supports the safe-landing ability of the system. Dutch roll suppression characteristics of the system were extremely impressive to this pilot and would allow landings to be done even in nonideal wind conditions. The PCA system exhibited great promise and if incorporated into future transport aircraft could further improve the safety of the passenger airlines.

Pitch control was outstanding, which allowed the pilot to work almost exclusively in the roll axis. Pilot workload in roll was high; however, it could have been significantly reduced if a heading hold featurc wcre incorporated.

Pilot $\mathrm{G}$ noted that the PCA flics the airplane really well. The thumbwheel concept is good, and the gains are just right. On the first approach, the airplane was real stable. This pilot was surprised at how well the PCA held glide slope. The roll response was really good. On the PCA go-around, this pilot was at a $-3^{\circ}$ glideslope at $100 \mathrm{ft}$ but put in a big nose-up command. Pilot G said, "I was confident of the go-around, which bottomed out $60 \mathrm{ft}$ above the ground." On the next approach to $50 \mathrm{ft}$. "I think you could get the airplane on the ground from this approach, in spite of the crosswind," pilot $\mathrm{G}$ continued.

Pilot C made several general (PCA) handling qualities comments. The aircraft responded adequatcly to all inputs commanded by this pilot. Pitch and roll responses were very sluggish, yet always consistent, and therefore predictable. The phugoid was surpressed by the system and was not noticeable except when making large changes in pitch. Dutch roll was very well controlled by the system. Generally, the system provided excellent fightpath stability and good control of the aircraft without being overly sensitive to gusts.

\section{Control Augmentation System Evaluation}

Pilots A through $\mathrm{H}$ commented negatively on the sluggish control, light damping, marginal stability, and high stick forces with the CAS-off. This situation provided a challenging environment for PCA control.

\section{Unusual Attitude Recovery}

Pilot $\mathrm{C}$ flew the aircraft clean, with CAS-off at $250 \mathrm{kts}$, $10,000 \mathrm{ft} \mathrm{MSL}$ to a $10^{\circ}$ flightpath angle and then banked to approximately $75^{\circ}$. Once this attitude was achieved, the flight controls were released, inlets were selected to emergency, and PCA was engaged. The PCA system alone was used to recover the aircraft. Initially, a level flight attitude was selected at the thumbwheels. The aircraft pitched up and basically entered the phugoid mode, slowing down in the climb. Right bank was selected with the thumbwheels to aid the nose drop and minimize the airspeed bleed off. While on the down side of the phugoid motion, the gear and flaps were extended. This extension occurred on the descending portion of the phugoid to minimize the effects of the increased pitching moment because of flap extension. Unusual attitude recovery was easy and effective using the PCA controls. At no time was the pilot concemed about the aircraft position because of PCA performance.

\section{Controls and Displays}

Pilots $\mathrm{A}$ through $\mathrm{H}$ found the thumbwheel controllers effective, properly scaled, and easy to use. They also liked the box on the HUD that indicated the flightpath command.

\section{Manual Throttles-Only}

No pilot was successful in the manual throttles-only approach. Pilot $\mathrm{C}$ observed that this mode of flight was extremely difficult if not impossible without a large amount of training. The major problem was controlling the phugoid in pitch, and the anticipation required to do that was monumental. Using differential thrust to control roll was marginal at best. Pilot $C$ discovered that it was fairly easy to use the wrong throttle when trying to control bank. The manual throttle-only flight condition was unsatisfactory and would not be recommended by this pilot in any ejection-seat-equipped aircraft.

\section{Recommended Improvements}

Improvements recommended by the pilots are provided next.

\section{Heading mode}

Pilot $\mathrm{H}$ commented on the desirability of a heading mode to be engaged on final approach to reduce the need to make constant bank angle inputs to hold heading. The PCA logic did incorporate a heading hold and a heading command feature. However, this logic had not been thoroughly tested, lacked a simple means of implementation, and was not flown by the guest pilots. 


\section{Altitude mode}

Pilot $\mathrm{D}$ commented on the desirability of a control mode to capture and hold a commanded altitude.

\section{Concluding Remarks}

An evaluation of a propulsion-controlled aircraft (PCA) system on an F-15 airplane has been flown. For comparison, manual throttles-only approaches were also flown. The following conclusions have been made:

1. The PCA system provides an effective method for flying an airplane without any flight controls. Safe landings have been made. Pilots felt confident enough to make landings on their first PCA flight.

2. The PCA pitch control was sluggish but very stable and predictable. Roll control was positive but lagged small inputs by about $3 \mathrm{sec}$. The pilots liked using the bank and flightpath angle thumbwheels.

3. The PCA engagements in upset conditions up to $90^{\circ}$ bank and $20^{\circ}$ dive were successful. These engagements showed that PCA has a good chance for recovering airplanes from flight control system failures, provided that the controls fail in a near-trim situation.

4. Manual throttles-only control is marginally possible for up-and-away flying. On the other hand, this control is not capable of making a safe landing for an airplane with such low natural stability as the F-15 airplane.

5. The F-15 airplane flown with the control augmentation system off has sufficiently poor stability and flying qualities to make it a very challenging application for PCA. Success of the F-15 PCA system in stabilizing this airplane indicates that other airplanes, such as large transports, which possess high levels of stability should have increased success with PCA systems.

6. Pilots were able to use the PCA system effectively on their first flight. They liked the stable pitch control and could adapt to the roll control. All of the pilots were able to complete approaches to the runway that they felt could have been carried on to safe landings.

\section{References}

'Burcham, F., Jr., Maine, T., Fullerton, C. Gordon, and Wells, Edward A., "Preliminary Flight Test Results of a Fly-By-Throttle Emergency Flight Control System in an F-15 Airplane," AIAA 93-1820, June 1993.

${ }^{2}$ Burcham, Frank W., Jr., and Fullerton, C. Gordon, Controlling Crippled Aircraft-With Throttles, NASA TM-104238, 1991.

${ }^{3}$ Gilyard, Glenn B., Conley, Joseph L., Le, Jeanette L., and Burcham, Frank W., Jr., "A Simulation Evaluation of a Four-Engine Jet Transport Using Engine Thrust Modulation for Flightpath Control," AIAA-91-2223, June 1991.

${ }^{4}$ Burcham, F., Jr., Maine, T., and Wolf, T., Flight Testing and Simulation of an F-15 Airplane Using Throttles for Flight Control, NASA TM-104255, 1992.

${ }^{5}$ Burcham, F., Jr., Maine, T., Fullerton, C. Gordon, and Wells, Edward A., Preliminary Flight Results of a Fly-By-Throttle Emergency Flight Control System in an F-15 Airplane, NASA TM-4503, 1993.

${ }^{6}$ Fullerton, C. Gordon, "Propulsion Controlled Aircraft Research," Proceedings of 37th Society of Experimental Test Pilots Symposium, Sept. 1993, pp. 78. 


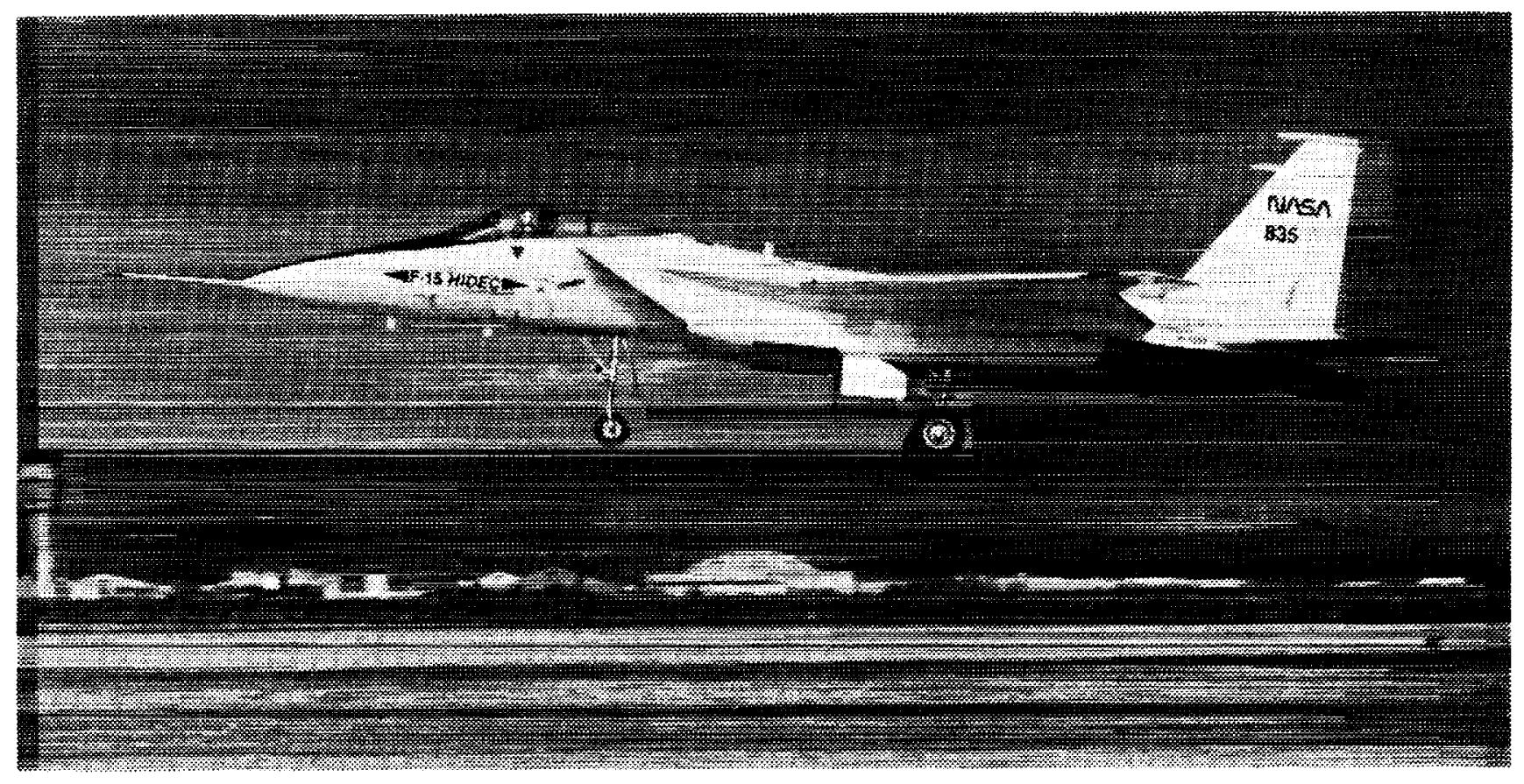

(a) The F-15 aircraft under propulsion-controlled aircraft control.

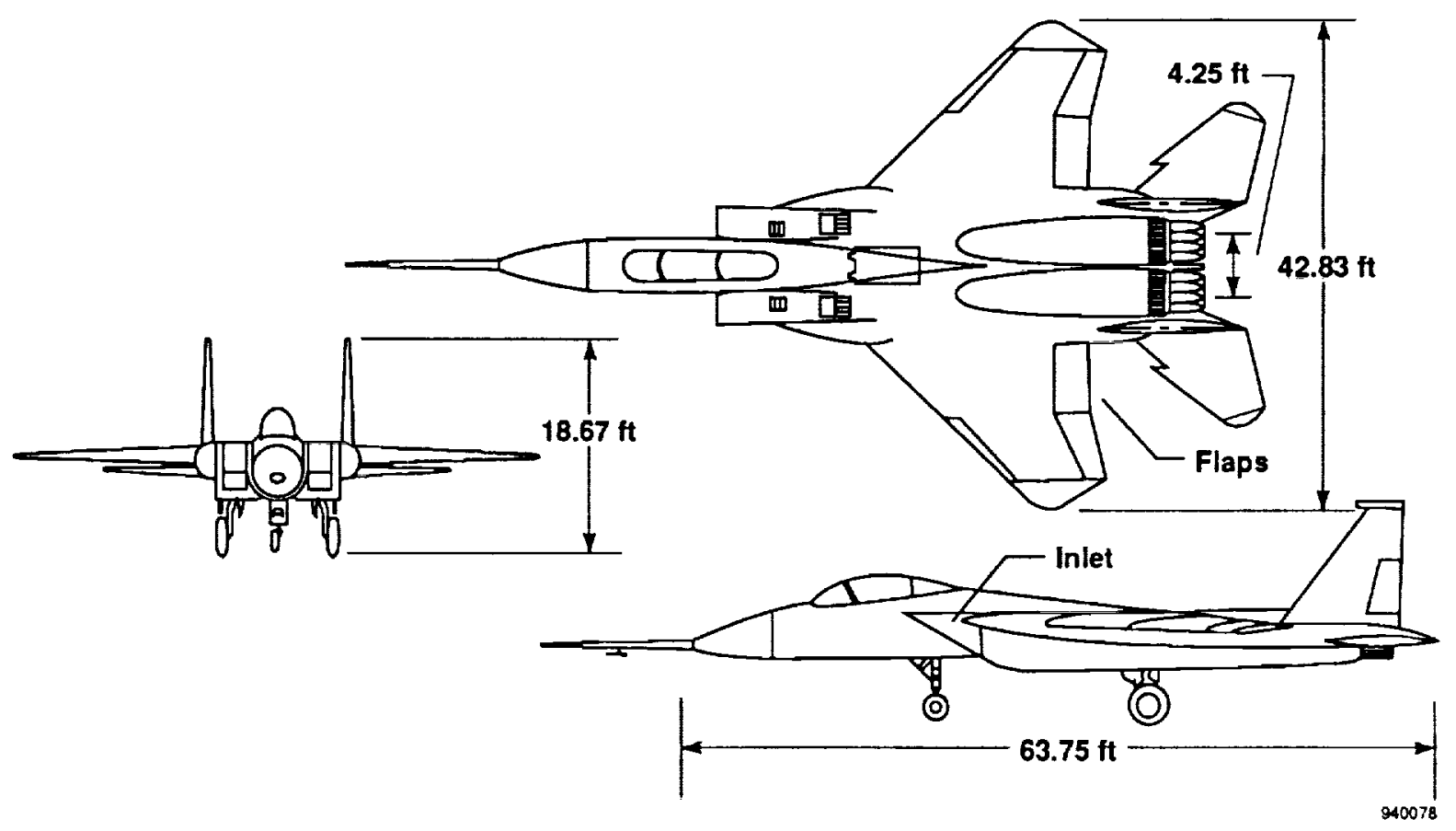

(b) Three-view drawing.

Figure 1. NASA F-15 Highly Integrated Digital Electronic Control flight research aircraft. 


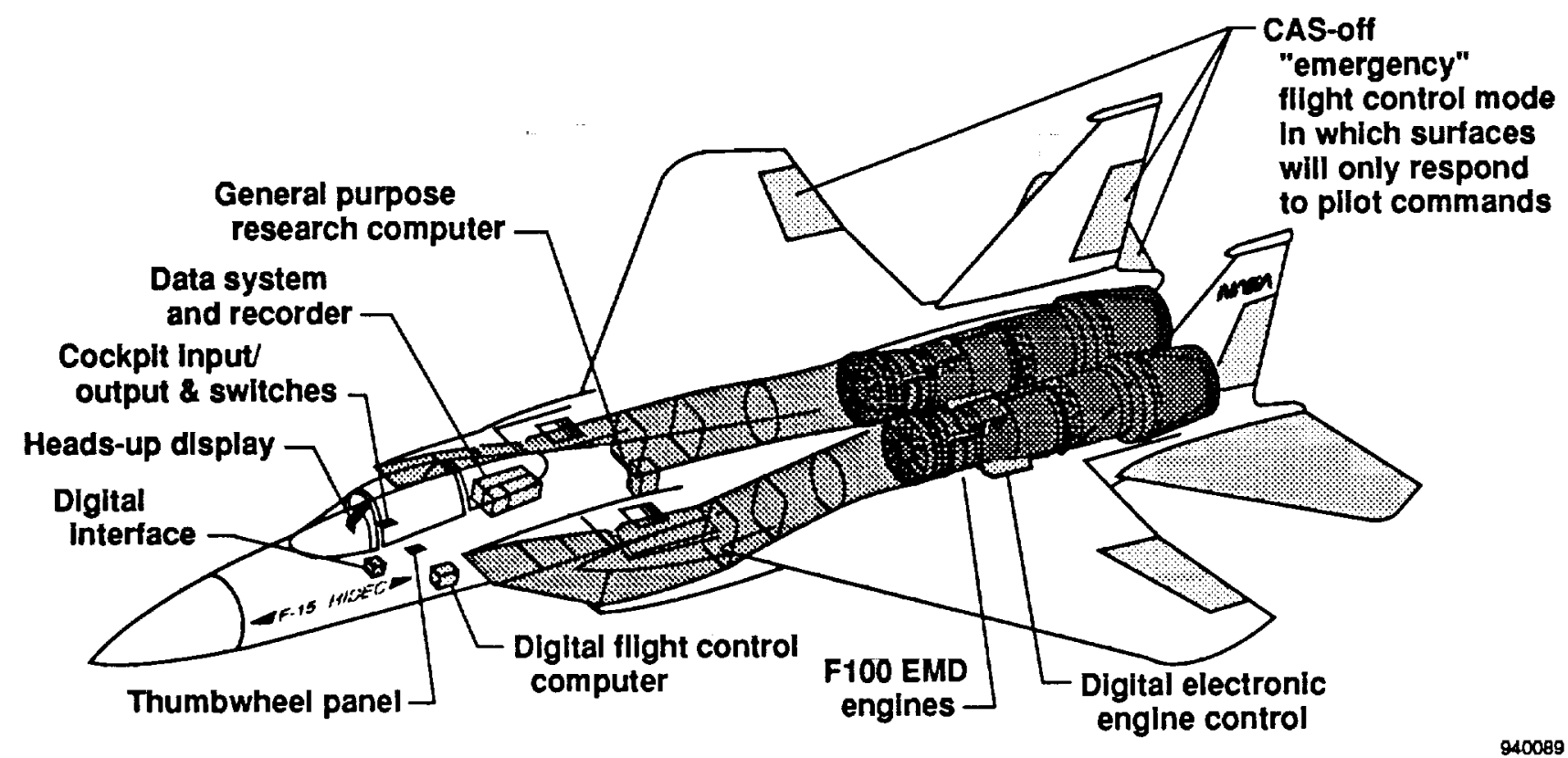

(a) Airplane and propulsion systems.

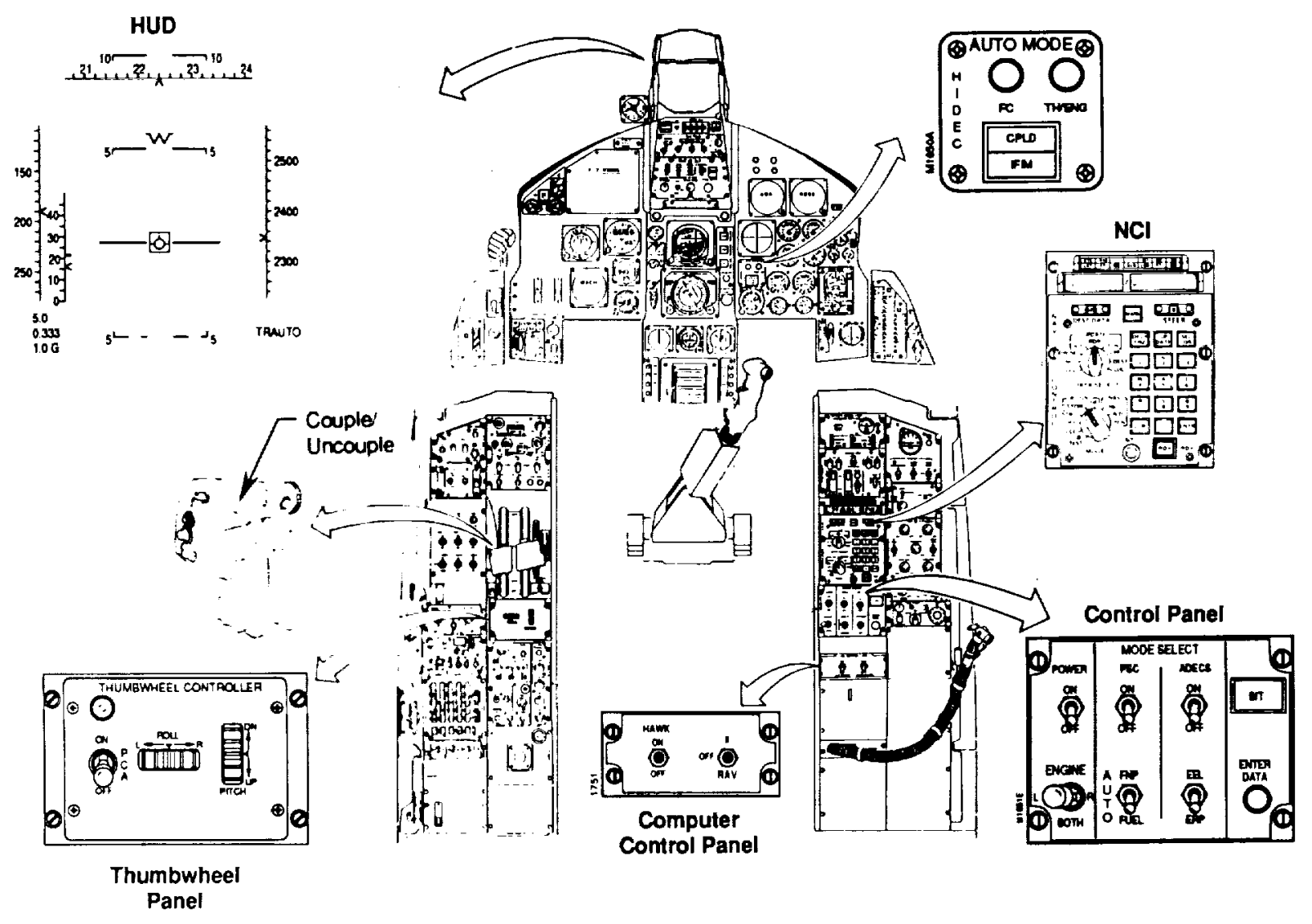

(b) The F-15 cockpit.

Figure 2. Intemal configuration for the F-15 propulsion-controlled aircraft. 


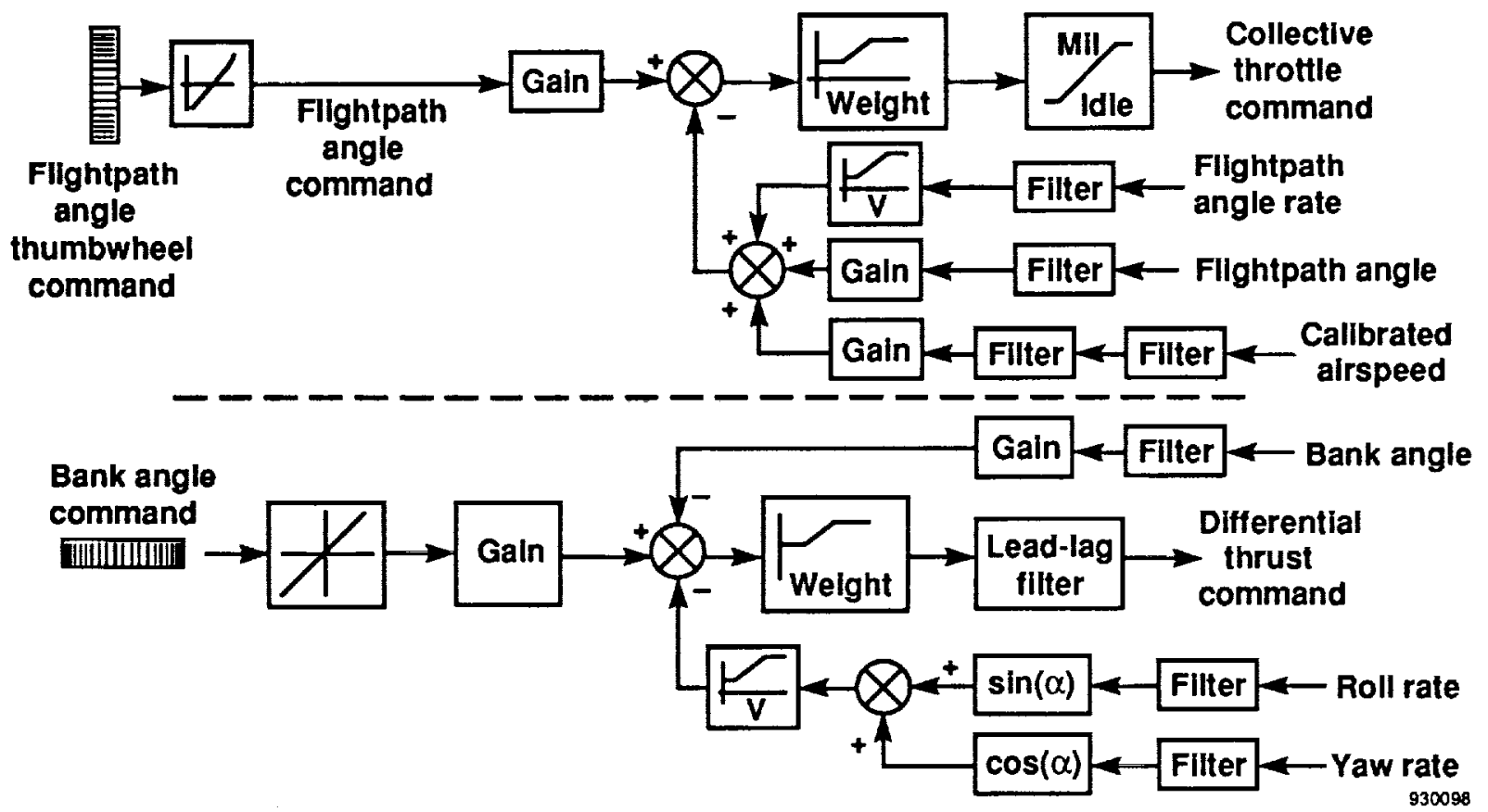

Figure 3. The F-15 propulsion-controlled aircraft logic. 


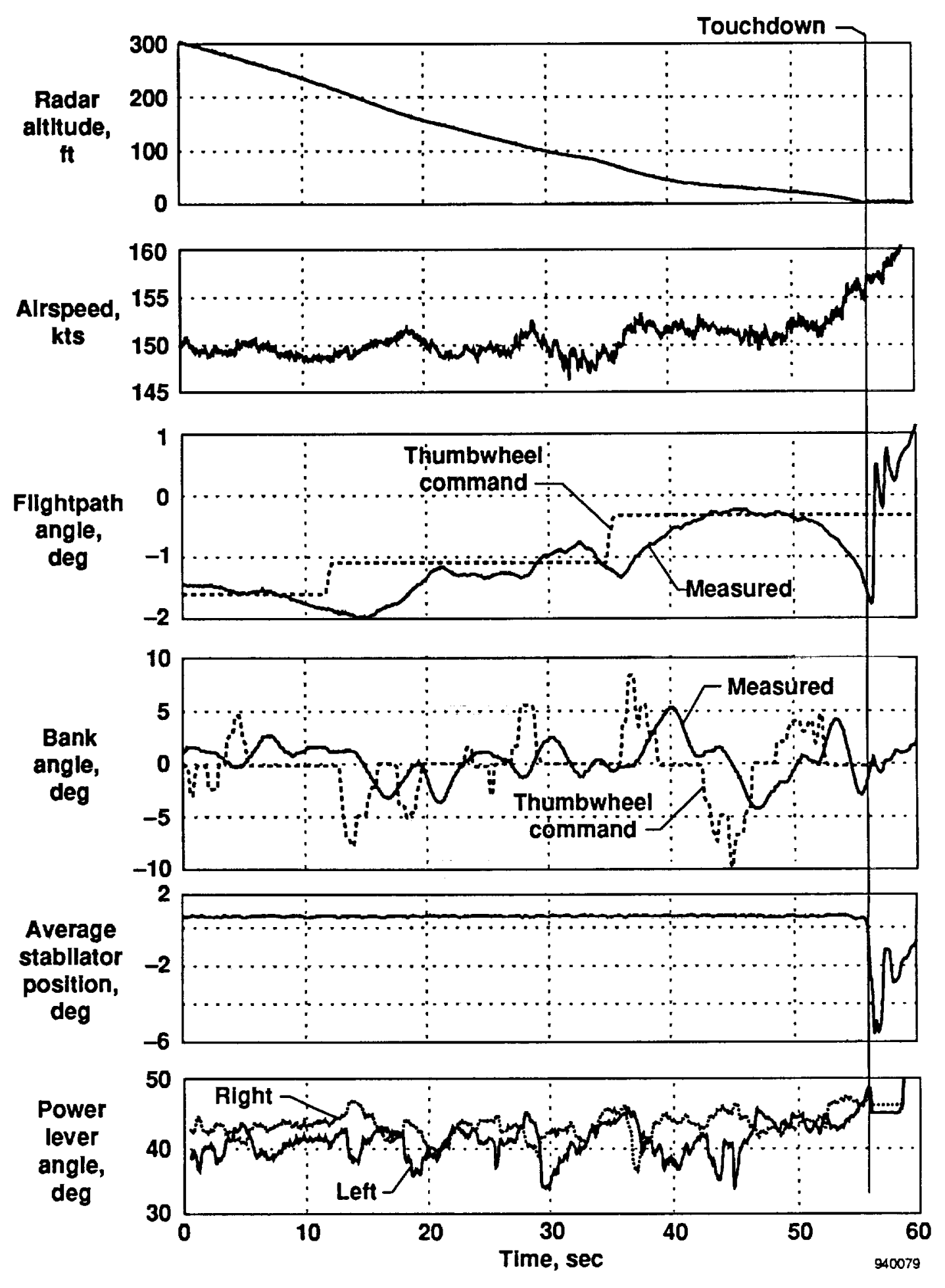

(a) Time history.

Figure 4. First propulsion-controlled aircraft approach and landing, gear down, flaps down, pilot A. 


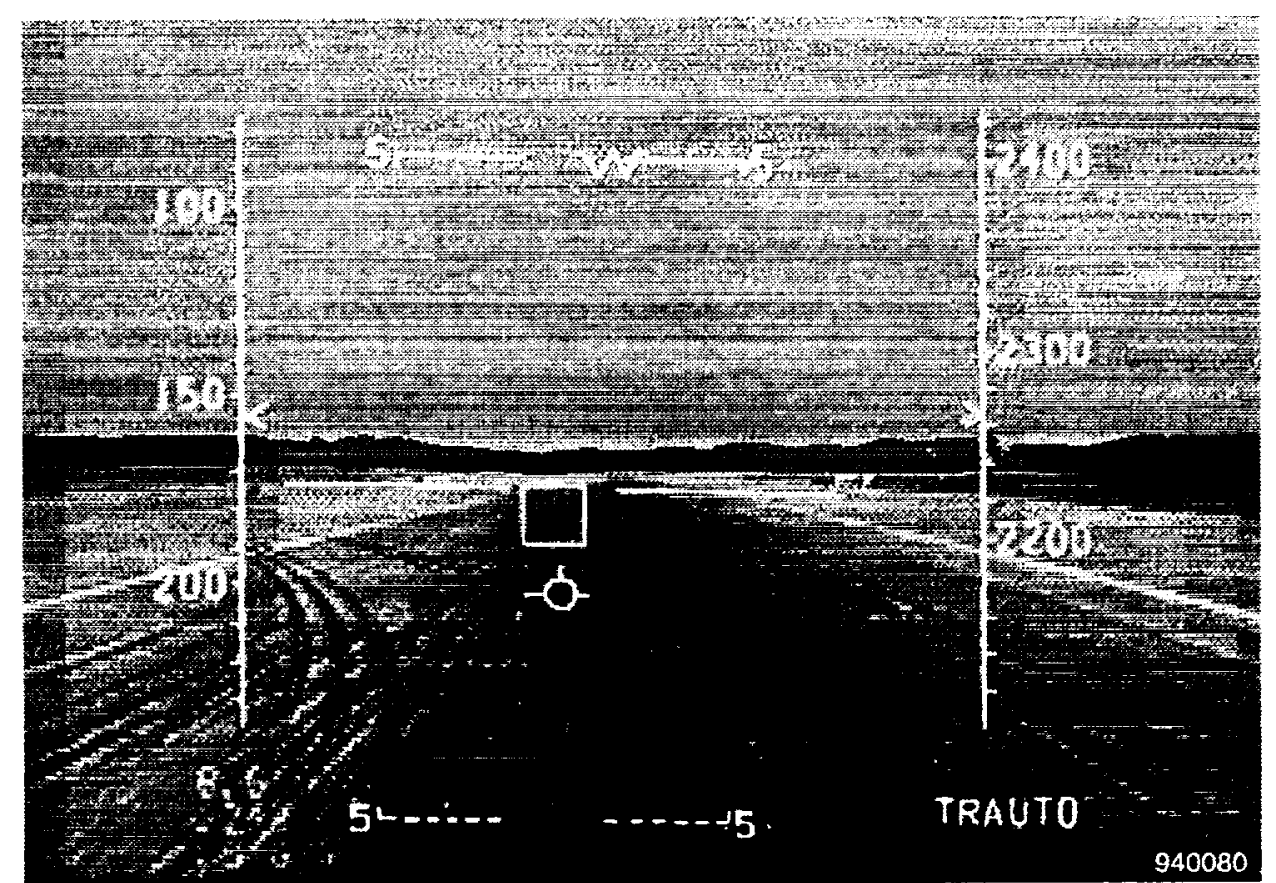

(b) Heads-up display video just before touchdown.

Figure 4. Concluded. 


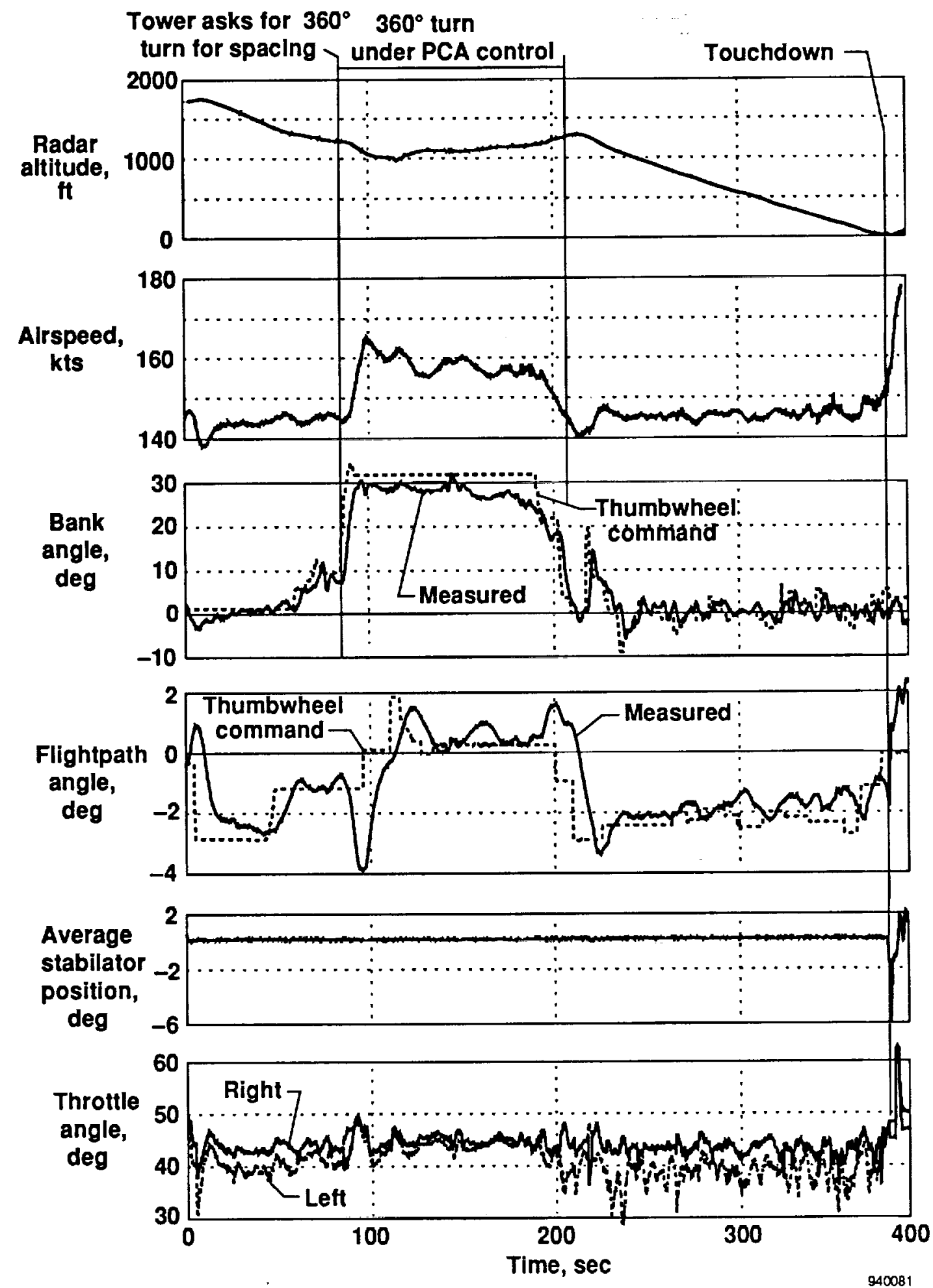

Figure 5. Time history of the second propulsion-controlled aircraft approach and landing, with a $360^{\circ}$ turn for spacing, pilot A. 


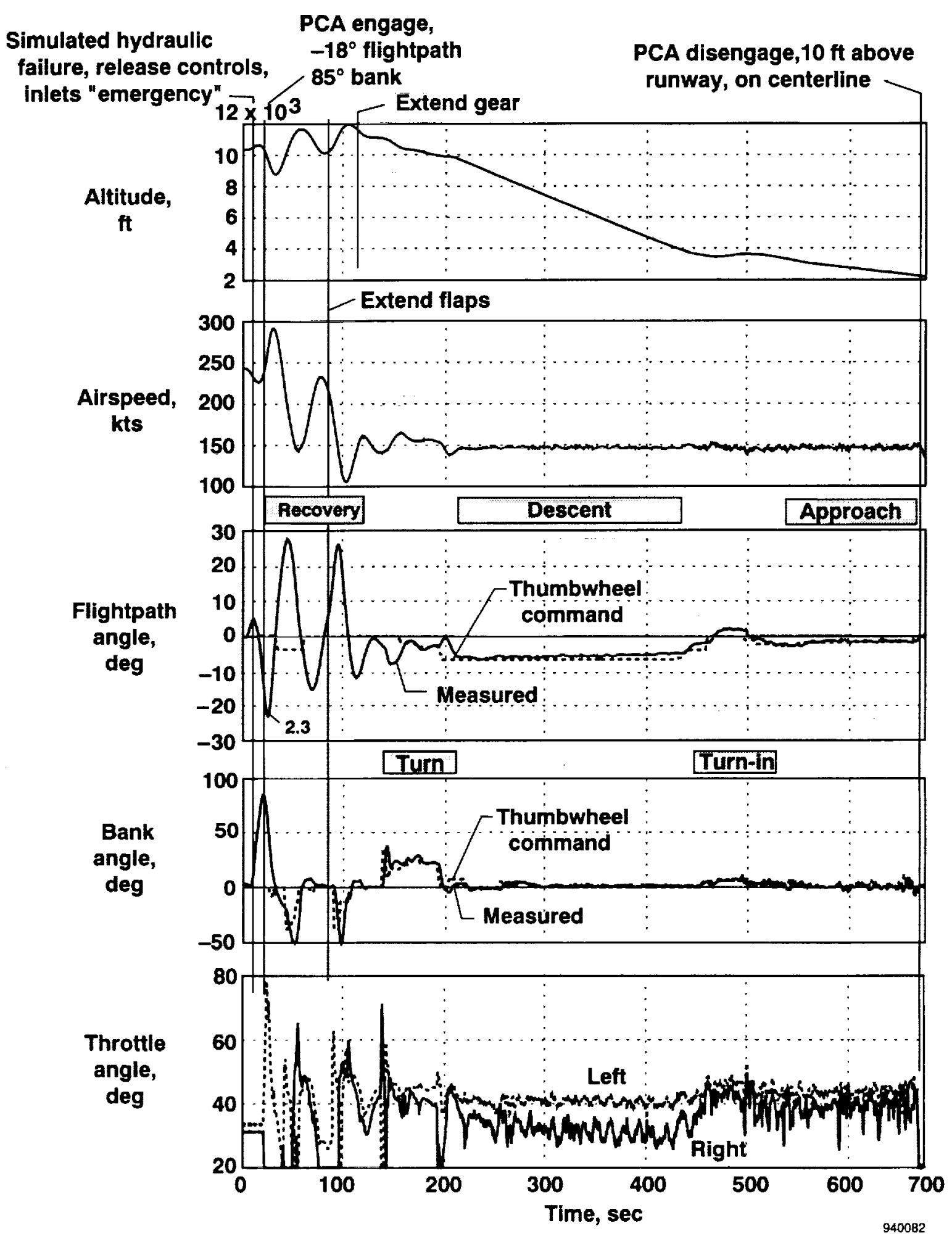

(a) Time history.

Figure 6. Simulated loss of flight controls upset, propulsion-controlled aircraft engagement, recovery, descent, and approach to landing, pilot $F$. 


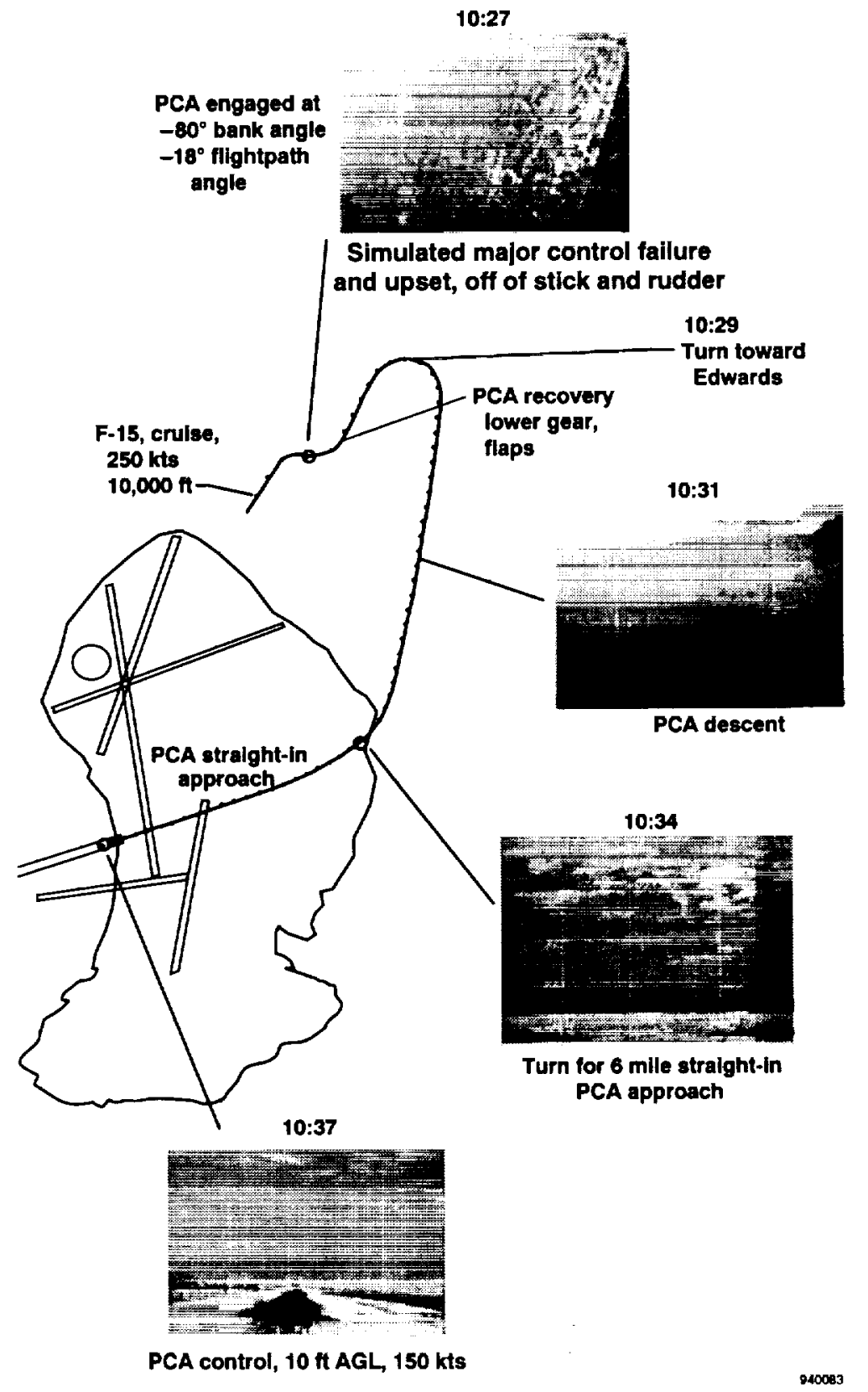

(b) Heads-up display video $10 \mathrm{ft}$ above ground level just before propulsion-controlled aircraft disengage.

Figure 6. Concluded. 


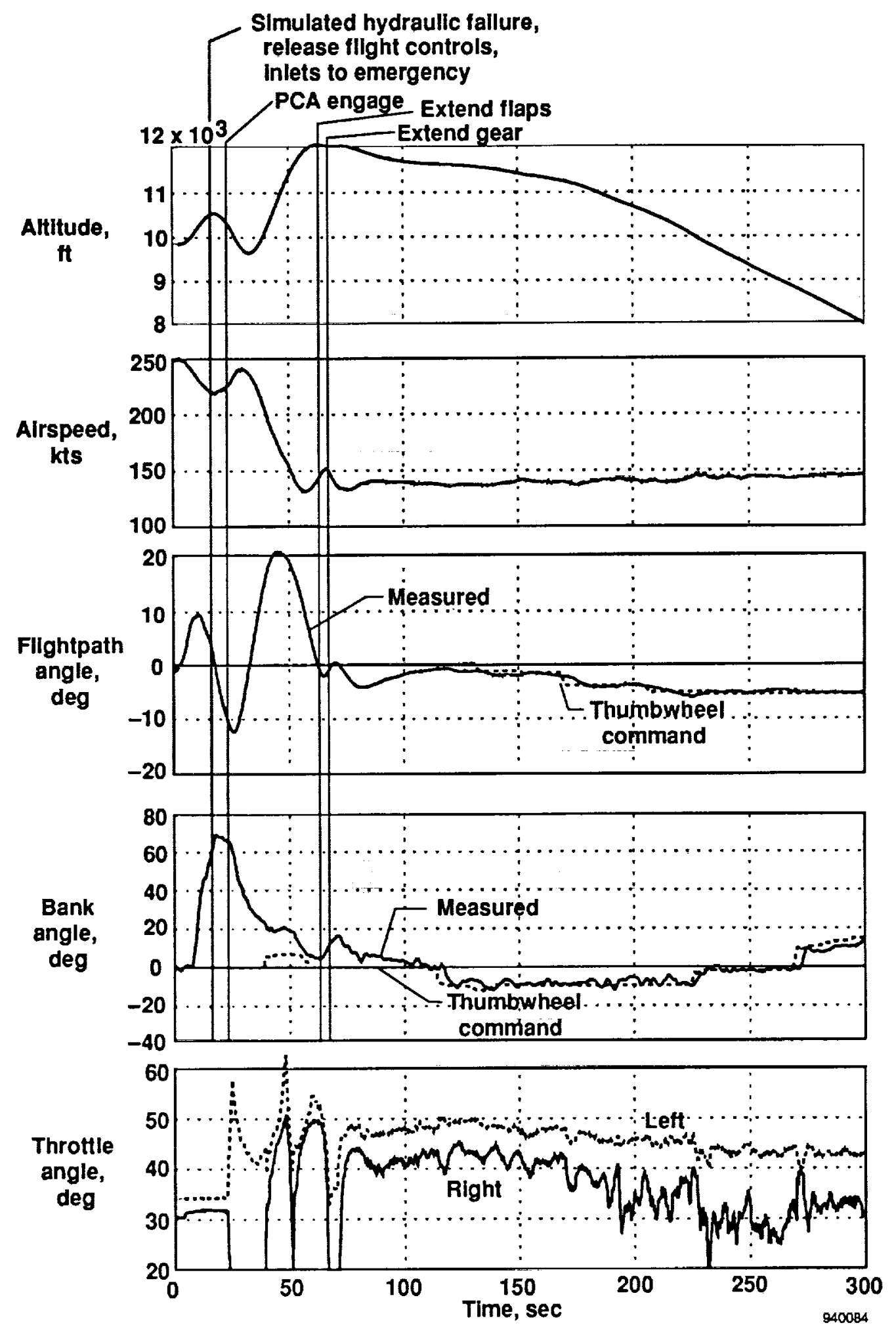

Figure 7. Time history of a simulated loss of flight control upset, propulsion-controlled aircraft engagement, recovery, and initial descent, pilot $\mathrm{H}$. 

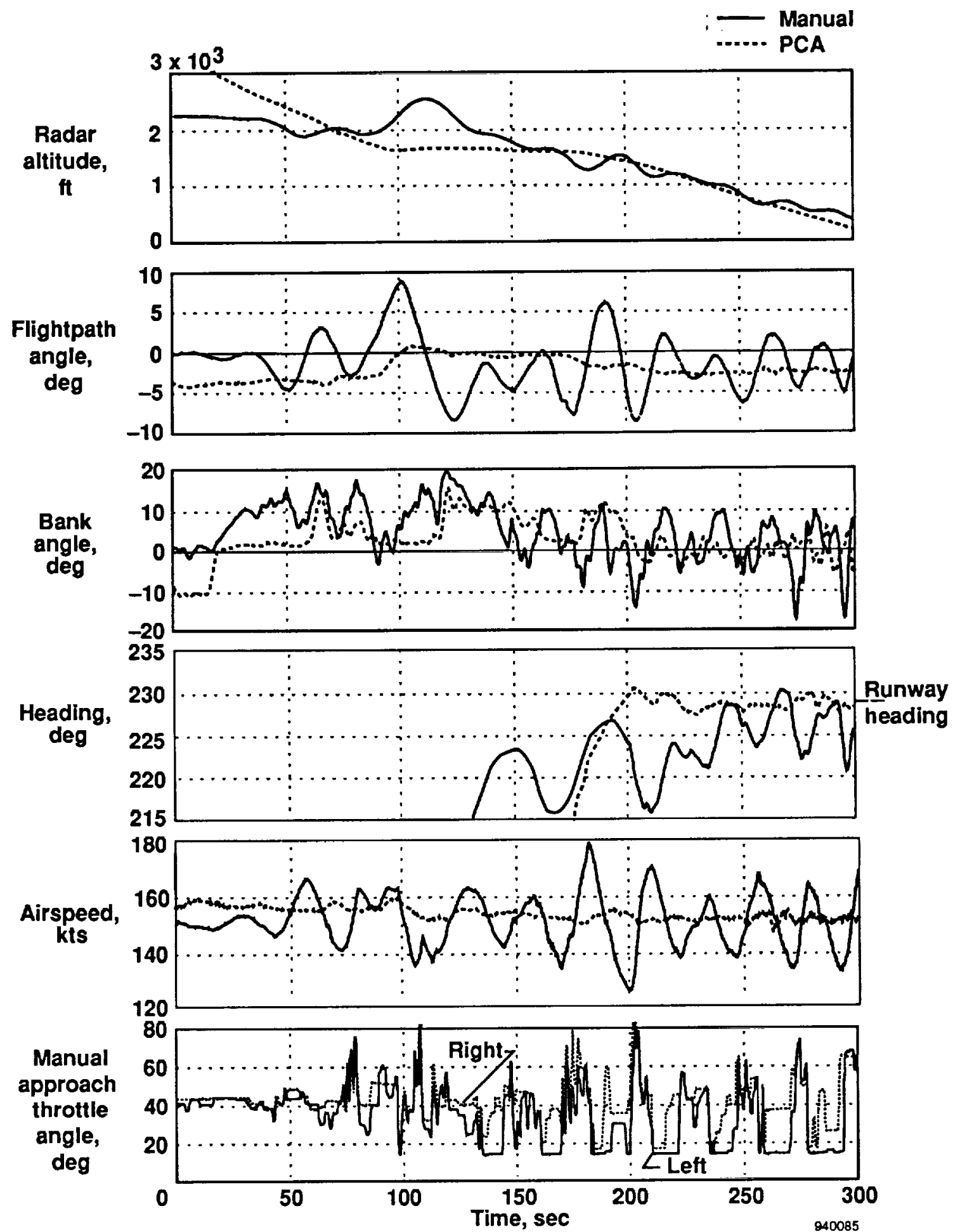

Figure 8. Time history of a control augmentation system off, manual throtles-only approach compared to the propulsion-controlled aircraft approach of figure 6, pilot $\mathrm{F}$. 
Public reporting burden for this collection of Information is estinated to average 1 hour per responee, induding the timn for reviewing inatructions, esurching existing dals sources,

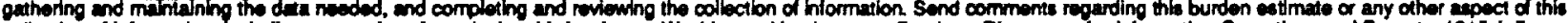
collection of informetton, Inctuding sugpections for reducing this burden, to Washington Headquartere Services, Directorate lor intormation Operations and Reports, 1215 Jeffereon

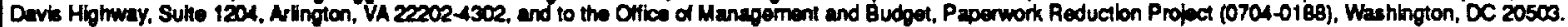

1. AGENCY USE ONLY (Leavo blank)

2. REPORT DATE

3. REPORT TYPE AND DATES COVEREO

June 1994

Technical Memorandum

4. TITLE AND SUBTTTLE

Flight Testing a Propulsion-Controlled Aircraft Emergency Flight Control

System on an F-15 Airplane

6. AUTHOA(S)

WU 533-02-34

F.W. Burcham, Jr., John Burken, and Trindel A. Maine

7. PERFORMING ORGANIZATION NAME(S) AND ADDRESS(ES)

NASA Dryden Flight Research Center

P.O. Box 273

Edwards, Califomia 93523-0273

8. PERFORMING ORGANIZATION REPORT NUMBER

H-1988

9. SPONSORING/MONOTORING AGENCY NAME(S) AND ADDRESS(ES)

10. SPONSORINGIMONITORING AGENCY REPORT NUMBER

National Aeronautics and Space Administration

Washington, DC 20546-0001

NASA TM -4590

\section{SUPPLEMENTARY NOTES}

Presented as AIAA 94-2123 at the 7th Biennial Flight Test Conference, June 20-23, 1994, Colorado Springs, Colorado.

12a. DISTRIBUTION/AVAILABILTYY STATEMENT

12b. DISTRIBUTION CODE

Unclassified-Unlimited

Subject Category 08

13. ABSTAACT (Maximum 200 words)

Flight tests of a propulsion-controlled aircraft (PCA) system on an F-15 airplane have been conducted at the NASA Dryden Flight Research Center. The airplane was flown with all flight control surfaces locked both in the manual throttles-only mode and in an augmented system mode. In the latter mode, pilot thumbwheel commands and aircraft feedback parameters were used to position the throttles. Flight evaluation results showed that the PCA system can be used to land an airplane that has suffered a major flight control system failure safely. The PCA system was used to recover the F-15 airplane from a severe upset condition, descend, and land. Pilots from NASA, U.S. Air Force, U.S. Navy, and McDonnell Douglas Aerospace evaluated the PCA system and were favorably impressed with its capability. Manual throttles-only approaches were unsuccessful. This paper describes the PCA system operation and testing. It also presents flight test results and pilot comments.

\begin{tabular}{|c|c|c|c|}
\hline \multirow{2}{*}{\multicolumn{3}{|c|}{$\begin{array}{l}\text { 14. SUBJECT TERMS } \\
\text { Emergency control, F-15 airplane, Flight test, Hydraulic failure, Propulsion-only } \\
\text { control }\end{array}$}} & \multirow{2}{*}{$\begin{array}{l}\text { 15. NUMBER OF PAGES } \\
21 \\
\begin{array}{l}\text { 16. PRICE CODE } \\
\text { AO3 }\end{array}\end{array}$} \\
\hline & & & \\
\hline $\begin{array}{l}\text { 17. SECURITY CLASSIFICATION } \\
\text { OF REPORT } \\
\text { Unclassified }\end{array}$ & $\begin{array}{l}\text { 18. SECURITY CLASSIFICATION } \\
\text { OF THIS PAGE } \\
\text { Unclassified }\end{array}$ & $\begin{array}{l}\text { 19. SECURITY CLASSIFICATION } \\
\text { OFABSTRACT } \\
\text { Unclassified }\end{array}$ & $\begin{array}{l}\text { 20. LIMITATION OF ABSTRACT } \\
\text { Unlimited }\end{array}$ \\
\hline
\end{tabular}

